\title{
Traditional Lowlands Water Management in Dano, South-Western Burkina Faso
}

\author{
Sié Pale ${ }^{*}$, Dapola Evariste Constant DA ${ }^{2}$ \\ ${ }^{1}$ Polytechnic University Center of Ouahigouya/Department of Atmosphere Sciences \\ ${ }^{2}$ University Ouaga I, Pr Joseph KI-ZERBO/Department of geography \\ Email: "palesie@gmail.com
}

Received 23 December 2015; accepted 9 April 2016; published 12 April 2016

Copyright (C) 2016 by authors and Scientific Research Publishing Inc.

This work is licensed under the Creative Commons Attribution International License (CC BY). http://creativecommons.org/licenses/by/4.0/

(c) (i) Open Access

\begin{abstract}
Lowland water resources management represents a challenge of the future that calls any community. Irrigated crops are grown in some areas of Burkina Faso, others are limited by a lack of irrigation infrastructure. Due to limited crop irrigation, crops and the associated populations dependent on them, depend on rain and on climatic factors. Thus, there is a need to understand and implement traditional mechanisms for managing lowland water in Dano, where climatic and geological conditions provide a sustained source of water. Here, I use a literature review combined with field work and interviews/questionnaires to estimate the potential exploitable plains to 16,056 ha or $24 \%$ of the communal area. Management mechanisms and traditional operating systems of lowland waters were clear, which helped to set the technological level of farmers, in partial control of water management.
\end{abstract}

\section{Keywords}

Burkina Faso, Dano, South Sudanese Climate, Lowlands, Traditional Management

\section{Introduction}

Traditional agriculture has long fed the rural population, however, erratic rainfall since the 1970s, degradation of natural resources (soil, water, vegetation) due to population pressure have contributed to decreased agricultural yields [1] [2].

Water deficiency due to climatic and anthropogenic factors and rapid population growth has reduced the availability of water and land per capita; it is one of the main factors responsible for this evolution which is explained by the decrease of agricultural production and forest resources [3]. Meanwhile, municipal needs facing

${ }^{*}$ Corresponding author. 
limited water resources have been increasing. This shows how it is essential to maintain the rural development programs, geared towards agriculture, particularly in sub-Saharan Africa. These programs have an obligation to simultaneously increase productivity, reduce poverty and improve gender equity; these are three factors that seem decisive for the improvement of food security [2]-[4].

The water supply off season for small productive activities such as gardening, fruit growing and nursery of exotic plants, helps to diversify agricultural activities and to cope with shortages of arable land [5]-[7]. Irrigation of small agricultural areas uses a variety of techniques. These have become more efficient in recent decades. This irrigation enables farmers to take advantage of the water available in rivers or aquifers to extend the production time, adding to traditional rainfall, those of dry season crops (contresaison) [8]-[11].

In Burkina Faso, the droughts of the 1970s and 1980s still mark deeply the lives of rural populations; they have led to environmental degradation, population movements towards the wetter areas and large cities, as well as a situation of continuing food insecurity [12]. These droughts are partly responsible for the impoverishment of populations, victims of a serious agro-ecological crisis and generate the progressive disintegration of traditional societies. The relationships between populations in dry regions and those irrigated areas are inevitably changed, evolving from a certain complementarity to forms of dependence [2] [13] [14].

With more than 2000 dams including 300 permanent and 8 large dams [15] [16] completed, often in earth and gabion baskets, and equipped with small irrigated areas downstream, Burkina Faso is a model for other SahelSudanese countries. These dams are the primary means of mobilizing surface water not only for agriculture but also for drinking water needs, animal husbandry and industry. Lowlands have been the target of many small improvements (filtering dikes, rice sills spilling). Access to these improved areas is difficult and often, the cause of exclusion of dominated social groups without land guarantees; these are notably women, newcomers, pastoralists and cadets [17]-[20].

The Water Resources development program in the South-west (Ressources en Eau dans le Sud-ouest: RESO) considered sustainable management with a blueprint and concerted planning, forming the framework of development stakeholders; it supports local initiatives through sub-programs focusing on assessment and recovery of water resources. Careful monitoring of innovations is made to conduct a consultation among stakeholders and empower them, by setting up agencies, basin Committees and Local Committees for Water (Comité Local de l'Eau: CLE). However, a general regulation blur is a handicap, combined with a lack of references and weak capacity of farmers. The integrated management approach does not yet seem quite understood by the operators [18] [21] [22].

If irrigated crops are possible in some areas of Burkina Faso, others suffer more from lack of irrigation infrastructure capable to regulate the problem of rural employment. In the case of Kou valley example, farming systems of the populations are mostly organized in strict rainfall crops, in lowland and small irrigation cultures practiced on developed areas and other so-called peripheral informal perimeters. These systems are weakly intensified, undiversified and offer a low productivity [23]. Now pushed toward the lowlands, previously unexploited areas [24], populations are still mainly engaged in traditional crops depending on climatic factors, particularly rainfall [25]. It is in this context that we have to know, how are the lowlands traditionally managed in Dano?

The general objective of this study is to explain the traditional lowland management mechanisms in Dano. What is the importance of agricultural lowlands of Dano Commune which occupies a favorable position in the climate area in terms of rainfall amounts? How is it managed in the current situation of natural resource degradation, coupled with the decline in rainfall and population pressure? At what level of water control the lowlands traditional management can be located?

\section{Methodology}

The approach uses the traditional data collection techniques, taking into account mainly the literature review and primary data collection. This approach is described on the following points:

\subsection{The Study Site}

Dano commune is located between $10^{\circ} 58^{\prime} 01^{\prime \prime}$ and $11^{\circ} 19^{\prime} 28^{\prime \prime} \mathrm{N}$ and, $2^{\circ} 49^{\prime} 48^{\prime \prime}$ and $3^{\circ} 11^{\prime} 20^{\prime \prime} \mathrm{W}$. Capital of the Province of Ioba, Dano covers an area of $669 \mathrm{~km}^{2}$ and has 22 administrative villages. It is located at a distance of $280 \mathrm{~km}$ from Ouagadougou [26] [27] (see Figure 1). 


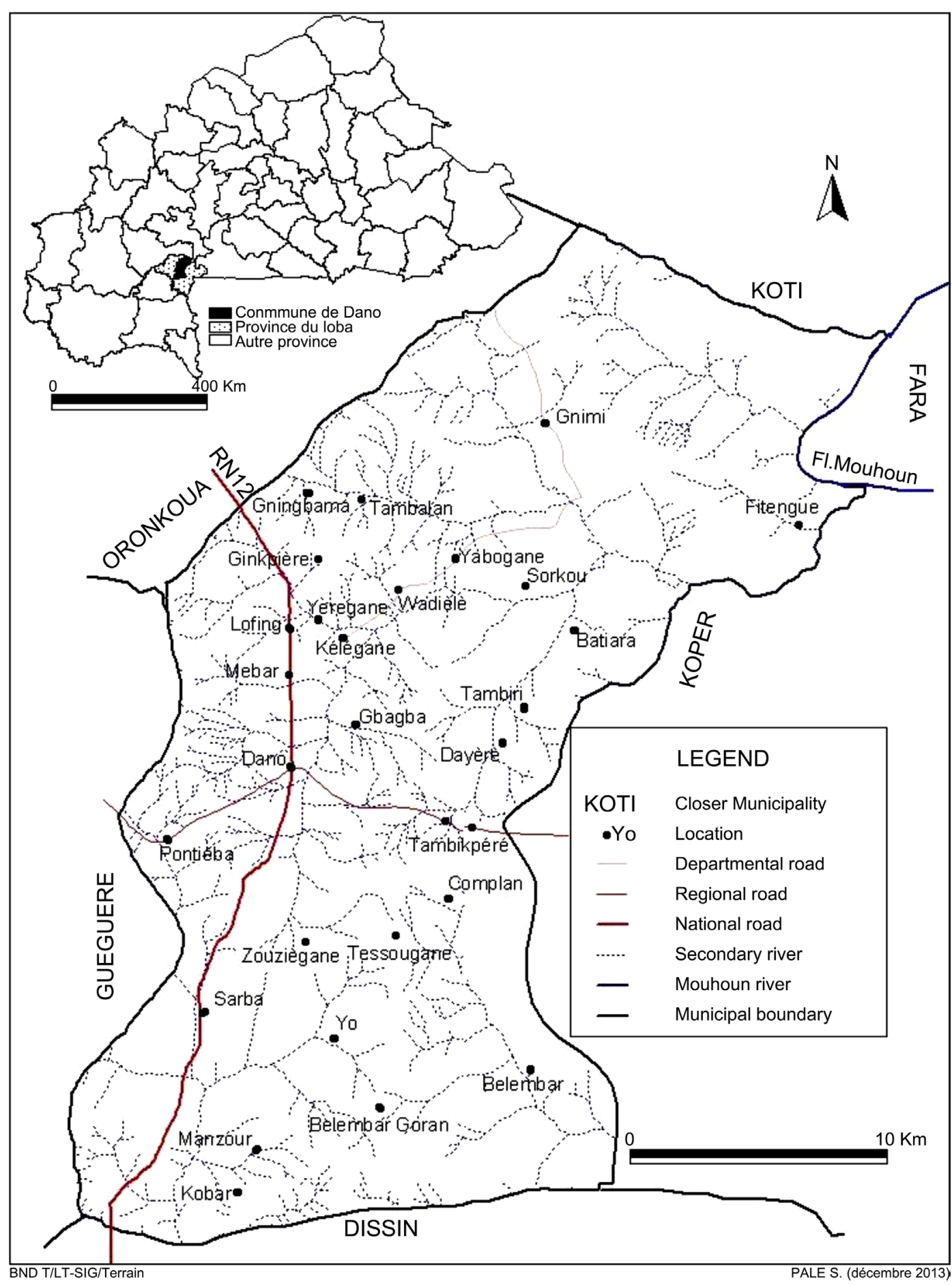

Figure 1. The town and surrounding Dano.

Climate field of Dano is South Sudan type characterized by the alternation of two distinct seasons (dry season that lasts six to seven months). The average annual rainfall exceeds $900 \mathrm{~mm}$.

The town of Dano is home to a variety of ethnic groups. The majority Dagara, coexist with Pougouli, Bwaba, Mossi and Fulani. Each of these ethnic groups, while following the dictates of his social organization, respects the customs and traditions of the other [26].

Agriculture is the main economic activity. It occupies more than $90 \%$ of the population. Agricultural production 
is mainly food-type. Indeed, during the 2003-2013 period, food crops (sorghum, millet, maize and rice) have held an average of $65 \%$ of planted areas against $34 \%$ for cash crops. Apart from rainfall, is practiced in the dry season, market gardening and growing small irrigation [28] [29]. Vegetable crops are grown in the lowland Lofing, around the Moutori dam and Pontièba water storage [26].

\subsection{The Literature Review}

In the literature, the channels used are the websites and documentation centers. Quantitative and qualitative data about study were collected through technical reports of the Ministry of Agriculture and non-governmental organizations, student dissertations and scientific articles. The relevance of the topics covered by the different authors and their areas of investigation were taken into account for the synthesis documents.

\subsection{The Primary Data Collection}

A survey was conducted among 96 lowland farmers in Dano Commune, particularly in sectors 3, 6 and 7 (Pontièba). The technique used is simple random sampling, without any statistical law. Interviews were also conducted with resource persons of services devolved to Dano such as the Provincial Director of Agriculture, Hydraulics and Fisheries, the Provincial Director of Environment and Sustainable Development, the municipality of Dano and the Dreyer Foundation. The collection tools used are designed to provide quantitative and qualitative data.

\subsection{Processing, Data Analysis and Presentation of Results}

Data from surveys and interviews are grouped according to our secondary research questions and the presentation of results in three parts. The first analysis allowed us to bring out an inventory of hydro-agricultural infrastructure in the form of a map using the Geographical Information Systems (GIS). Then, mechanisms and traditional management systems of the lowlands are mentioned and finally, an analysis is made followed by discussions to locate the degree of technological implication of this rural population particularly in lowlands water resources management.

\section{Results and Discussion}

The results obtained follow the implementation of a methodological approach described below:

\subsection{Areas of Lowland}

The integration of rice as a cereal camp enabled local people to briefly occupy the floodplains. The BUNASOLS's work in 2000 [30] have established agronomic abilities of soils for the main cereals produced in Dano, including units capable of providing double cropping, rainfall and dry crops, as shown in Table 1.

By observing this table, agronomic units capable of supporting rice cultivation, which most often occupy flood areas or slums, are the units 1,2 and 3 having an average ability $\left(\mathrm{S}_{2 \mathrm{n}}\right)$. It's all ferruginous leached hydromorphic soils, leached ferruginous soils on indurated inclusion, waterlogged soil surface pseudogley and slightly evolved hydromorphic alluvial soils intake. The area they occupy equivalent to $24 \%$ of the total area of the municipality [27] (see Figure 2). These soil types also support the culture of other cereals mentioned in the above table. The other soil types, unit 3 consists of hydromorphic soils low in humus surface pseudogley $\left(\mathrm{S}_{3 \mathrm{w}}\right)$; unit 4 of leached tropical ferruginous soils moderately deep indurated and indurated deep leached tropical ferruginous soils $\left(\mathrm{S}_{3 \mathrm{r}}\right)$; unit 5 , unfit for any cereal production $\left(\mathrm{N}_{2}\right)$, includes lithosols on rock, lithosols on ironstone, leached superficial indurated ferruginous tropical soils and indurated ferruginous leached deep soils [27] [31] [32].

Compared to the density of the river system, the proportion of lowland soils appears low because of the terrain. As a reminder, hills, mounds and glazes dominate the landscape Dano. However, note that $24 \%$ of potential land for rice cultivation and/or contresaison (dry crops) is not negligible. Expressed in hectares, this percentage amounts to 16,056 ha, or about $7 \%$ of the national potential [33].

So far, four sites are involved in vegetable production in the dry season; the lowland Lofing, withholding water of Ligmarè and Pontièba and the Moutori landscaped perimeter. It is the latter that is most important with 23 ha of exploiting area [31]. Except the area of Ligmarè which is purely operated traditionally, others experienced an arrangement with irrigation channels in Pontièba and Moutori, and culvert wells at Lofing. 


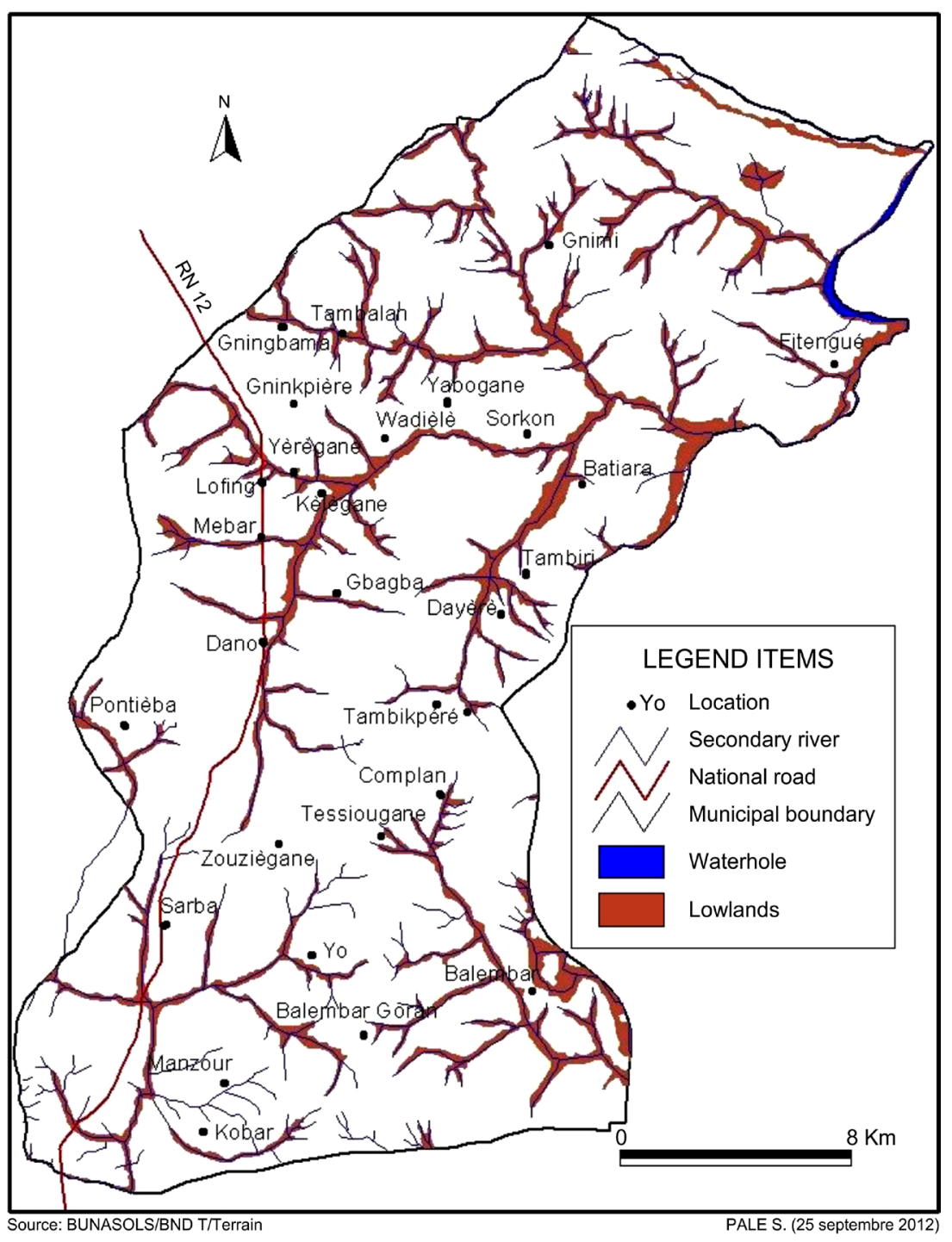

Figure 2. The extent of lowlands in Dano.

Table 1. Ability soil agronomic units for grain Dano.

\begin{tabular}{cccccc}
\hline Agronomic Units & Proportion (\%) & Maize & Millet & Sorghum & Rice \\
\hline 1 & 10 & $\mathrm{~S}_{2 \mathrm{n}}{ }^{*}$ & $\mathrm{~S}_{2 \mathrm{n}}$ & $\mathrm{S}_{2 \mathrm{n}}$ & $\mathrm{S}_{2 \mathrm{n}}$ \\
2 & 1 & $\mathrm{~S}_{2 \mathrm{n}}$ & $\mathrm{S}_{2 \mathrm{n}}$ & $\mathrm{S}_{2 \mathrm{n}}$ & $\mathrm{S}_{2 \mathrm{n}}$ \\
3 & 13 & $\mathrm{~S}_{3 \mathrm{w}}{ }^{* *}$ & $\mathrm{~S}_{3 \mathrm{w}}$ & $\mathrm{S}_{3 \mathrm{w}}$ & $\mathrm{S}_{2 \mathrm{n}}$ \\
4 & 35 & $\mathrm{~S}_{3 \mathrm{r}}$ & $\mathrm{S}_{3 \mathrm{r}}{ }^{* * * *}$ & $\mathrm{~S}_{3 \mathrm{r}}$ & $\mathrm{N}_{2}$ \\
5 & 41 & $\mathrm{~N}_{2}^{* * * *}$ & $\mathrm{~N}_{2}$ & $\mathrm{~N}_{2}$ & $\mathrm{~N}_{2}$ \\
\hline
\end{tabular}

Source: Based AGRITECH FASO (2010).

Please note: ${ }^{*} \mathrm{~S}_{2 \mathrm{n}}=$ average ability; ${ }^{* *} \mathrm{~S}_{3 \mathrm{~W}}{ }^{* * *} \mathrm{~S}_{3 \mathrm{r}}=$ marginal ability; ${ }^{* * * *} \mathrm{~N}_{2}=$ permanently incapacitated.

\subsection{Traditional Management Mechanisms of Water Resources}

The right to water is closely linked to that of the land which is acquired by the principle of the precedence or seniority. And control of traditional water management (TWM) systems (Gestion Traditionnelle de l'Eau: GTE) is 
provided by traditional leaders who are indigenous. These TWM or GTE (in French) are governed by customary law with a village ownership [34]. Only holders' customary rights generally inherited through the oral tradition. Recently, SOME J-M [35] mentions that on the earth, the heirs are fighting to avoid spoliation operated by the state or foreign powers. Their struggle, which is not just only a defense of any property, takes the form of a crusade to ensure that land managers who received this "gift of the earth" know their rights, while remaining open to trade necessitated by (and for) the development [36]-[38].

The land crops in the lowlands are obtained by inheritance father to son, nephews and cousins. In the community, no woman can be hold land. According to the survey results, the powers of such land plots, that is to say to foreign applicants to the family, are only temporary and the owners have the right to demand it at any time [36].

The exploitation of surface waters in the lowlands is allowed for all inhabitants of the land. In the dry season, the water in the troughs is in the form of beads; in places, wells are dug to overcome the problem of watering animals and gardening. Furthermore, the animals must be kept away from existing fields, to avoid internal disputes within the village. To this end, corridors of access to water points and grazing areas are drawn.

\subsection{The Traditional Lowlands Operating Systems}

In the lowlands, farmers traditionally sown early in the rainy season after summary farming methods performed with the daba. The first floods come as the seedlings are large enough to support them [39]. Compared to the farmers of developed areas, those who practice purely rain-based watering, recognize that they are taking longer to produce or grow than previous. The plots are prepared before or during the first rains; it is a simple plowing by the hoe or large mounds of at least 2 square meters of 30 to $50 \mathrm{~cm}$ in height and spaced from each other by at least $1 \mathrm{~m}$. These mounds can be made in rows or staggered; farmers prefer the latter provision to slow water currents capable of carrying some mounds.

Seedlings also follow a certain logic (as a reminder, all farmers practice mixed farming in the operating system); on mounds, corn is planted, often accompanied okra around them. Some mounds may also harbor Cucurbitaceae (gourd family), especially the squash to be harvested before the floods. The spaces between the mounds are exclusively rice (long cycle, traditional, 4 - 5 months). To slow runoff and erosion, seedlings are usually arranged in staggered rows (see Figure 3(a) and Figure 3(b)).

In the case of gardening, which lasts 3 - 4 months from November to February, the boards are inter-spaced not more than $50 \mathrm{~cm}$. Common vegetables such as tomatoes, eggplants, okra, peppers, cabbage and increasingly onion are produced. Traditional operators recognize they have no control in the production of onion. Figure 4 presents a technique traditional operating lowlands to Ligmarè.

\subsection{The Degree of Technological Involvement of Farmers in Traditional Management of Water Resources}

Water and land are seen as divine gifts, often representing a relationship between God, genies, and human beings; they are sacred elements related to the ordering in different societies. Water resources control forms are always determined by this design [40]. The need to fill a food deficit facing erratic rainfall and a population explosion that compresses the cultural space, led farmers to focus more on floodplains [41]. Lowlands in Dano, formerly used for growing tobacco, pepper or eggplant are nowadays exploited for cultivation of cereals, including maize and rice. This enthusiasm comes from the strong climate variability that becomes elusive for farmers. The 2012 IUCN report on wetlands, with reference to flood areas or lowlands, particularly in France, confirms this argument; for her, wetlands have also long been seen as detrimental ecological environments, which would explain the many improvements made over time. Nowadays, these wetlands regress due mainly drainage for agricultural purposes [24]. Thus, rice production is growing for a decade and forcing rural people to a new civilization with water [42]-[44]. The three types of production such as irrigated rice, rice lowland and upland strict that are practiced throughout the town. Nationally, the Ioba Province is one of provinces occupying the 3rd rank rice production [45].

Rice production in Dano has become a booming business and the degree of involvement of farmers in water management is increasingly important. The peasant effort is laudable even if the majority does not have total control of agricultural water. The gradual intensification of agriculture requires more efficient water management. And a key to the problem of water for the rural world is the creation and multiplication in recent years, developed areas [46]. The results show the existence of three types of lowland occupied by farmers. First, traditionally 

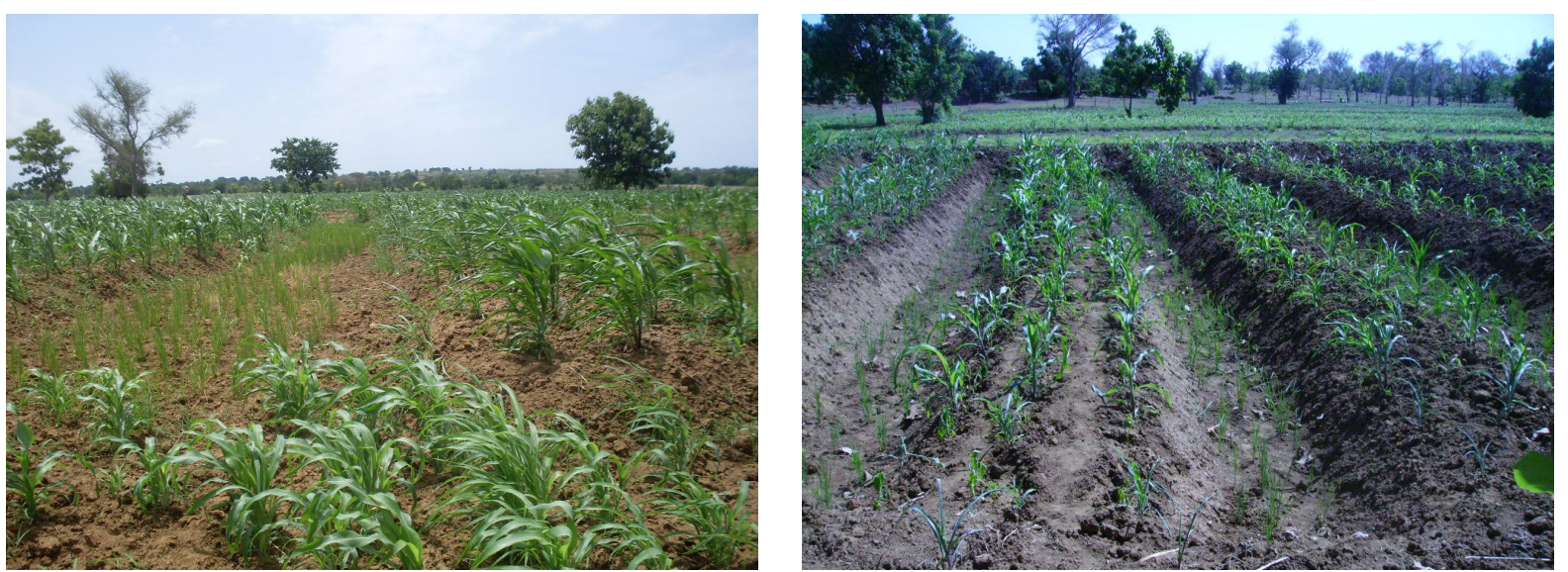

Source: PALE S. (June 2012).

These two pictures show two ways to carry out the mounds in the lowlands and arrangement of crops; we clearly observe the alternation of sowing on the microtopography created by farmers (corn on small hills and rice between them).

(a)

Figure 3. Arrangement of mounds and types of crops in traditional farming to lowlands in Dano.

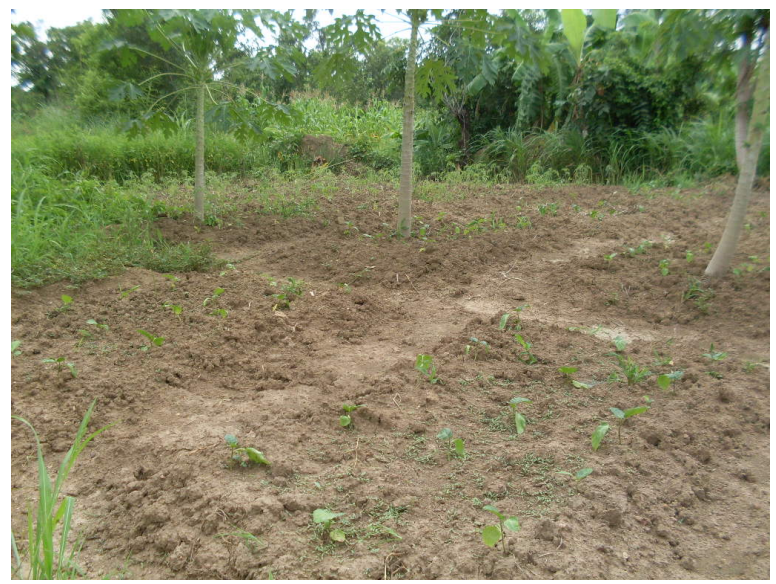

Source: PALE S. (June 2012).

The illustration shows the boards with regular shapes separated from each other by an alley of about $50 \mathrm{~cm}$. They wear tomato plants in the background and those of eggplant forward; it is the garden below the dam of Ligmarè, $15 \mathrm{~km}$ from Dano, further south.

Figure 4. Arrangement of boards and cultures within a garden in Ligmarè lowland (South Dano).

exploited lowlands are most prevalent; then the simple managed lowlands and finally the improved one. It should be noted here that these three groups of lowland could not be quantified. So, the degree of involvement in the peasant agricultural water management is at three levels; respectively between those who have had no training, those who have benefited from training or study tours and those who are permanently assisted by agricultural technicians [47].

The main coaching topics for those receiving assistance include the application of technical ideas, composting, respect the cropping calendar and interviews plots. The purpose of the application of this technology package is to enable producers to improve yields in their plot. Unfortunately, they often face due to insufficient number of breaks support technicians. This inadequacy of the staff hampers the normal monitoring of producers and promotes non-compliance with rules set in different arrangements [39].

At this stage, a tiny fraction of Dano rural population receives training or partial control study trips water. The majority of farmers expressed their enthusiasm to exploit in the irrigated perimeter of Moutori or, at best, to 
usurp technology. Unfortunately, this technology package seems to monopolize their complex because of the lack of equipment and infrastructure, income poverty and to appropriate it as illiteracy or low educational attainment. This is a commitment, determination, and even an awareness of rural population to move to other technologies to improve crop yields; this deserves special attention of policy makers and NGOs for them.

\section{Conclusions}

Geological formations and exogenous agents of erosion have promoted a relief accident in the Dano Commune. It forms a dendritic network of streams rather important in more or less cramped plains. These floodplains reported in the area of the town, occupy $24 \%$ or 16,045 ha. These lowlands are traditionally run by local people. And management mechanisms are based on the prior definition of allocation with the involvement of the beneficiaries, when it comes to amenities or are provided by traditional leaders who are indigenous.

Water control is located at three levels according to the three types of lowland identified (purely traditional lowlands, simple managed lowlands and improved lowlands). Thus, it appears that only a small portion of this population has partial control of water.

Attention of policy makers and humanitarian organizations working in the field of rural development, must be paid to this population that expresses a strong enthusiasm to go to other supposedly improved technologies that can increase agricultural production in the storm system and gardener.

\section{References}

[1] Mahé, G., Diello, P., et al. (2010) Declining Rainfall and Increased Flows in the Sahel: Climate and Human Impact on the Nakambe Flows in Burkina Faso [Baisse des pluies et augmentation des écoulements au Sahel: Impact climatique et anthropique sur les écoulements du Nakambe au Burkina Faso]. Sécheresse, 21, 1-6.

[2] PNUE (2002) 3rd Joint Regional Meeting of National Coordinators and the Committee "Project of integrated water resources management and Volta Basin lands”, Accra, 9-10 December 2002. Mission Report. [3 ${ }^{\text {ème }}$ Réunion Régionale conjointe des coordinateurs nationaux et du comité du "Projet de gestion intégrée des ressources en eau et des terres du bassin de la Volta”, Accra, du 9 au 10 décembre. Rapport de Mission], MAHRH/DGIRH, Burkina Faso, 34 p.

[3] Bognini, S. (2011) Impacts of Climate Change on Vegetable Crops in Northern Burkina Faso: Case of Ouahigouya [Impacts des changements climatiques sur les cultures maraîchères au nord du Burkina Faso: Cas de Ouahigouya]. RENAF/SMHI, Ouagadougou, 38 p.

[4] FAO (2002) Water and Agriculture, Producing More with Less Water [Eau et agriculture, produire plus avec moins d'eau]. FAO/FIAT/PANIS, Rome, 28 p.

[5] Dipama, J.-M. (2004) Peasant Perception of Environmental Degradation on the Perimeter of Kompienga Dam (Burkina Faso). In: Priorities and Practices of Rural Development in Sub-Saharan Africa [Perception paysanne de la dégradation de l'environnement sur le pourtour du lac du barrage de la Kompienga (Burkina Faso). In: Priorités et pratiques du développement rural en Afrique subsaharienne.] Univ. Ouagadougou/IDR/UPB/DANIDA, Ouagadougou, 149-164.

[6] FAO (2008) Water and Rural Poverty: Interventions for Improving Livelihoods in sub-Saharan African Populations [Eau et pauvreté rurale: Interventions pour améliorer les moyens d'existence des populations d'Afrique subsaharienne]. FAO/FIDA, Rome, 126 p.

[7] Laouina, A., Aderghal, M., Al Karkouri, J., Chaker, M., Machmachi, I., Machouri, N. and Sfa, M. (2010) Land Use, Runoff and Land Degradation: Case of Sehoul Zone, Atlantic Region (Morocco) [Utilisation des sols, ruissellement et dégradation des terres: Le cas du secteur Sehoul, région atlantique (Maroc)]. Sécheresse, 21, 309-317.

[8] Bouaicha, R. and Benabdelfadel, A. (2010) Variability and Surface Water Management in Morocco [Variabilité et gestion des eaux de surface au Maroc]. Sécheresse, 21, 1-5.

[9] Cessouma, A. (2008) Irrigated Agriculture and Water Saving Opportunities in Mali [L'agriculture irriguée et les perspectives d'économie d'eau au Mali]. Revue HTE No.141, décembre, Rabat/Maroc, 4-6.

[10] Chahbani, B. (2004) Technical Innovations for Optimizing the Collection, Conservation and Water Use for Sustainable Development of Rainfall Agriculture in Arid Regions [Innovations techniques pour l'optimisation de la collecte, de la conservation et de l'utilisation de l'eau pour un développement durable de l'agriculture pluviale dans les régions arides]. Institut des Régions Arides, Tunisie, 73-78.

[11] El Garouani, A. and Merzouk, A. (2010) Geomatics Approach for Defining Protection Areas for Groundwater Resources (Well-Field) [Approche géomatique pour la délimitation des périmètres de protection des ressources en eau souterraines (champ captant)]. http://www.secheresse.info/spip.php?article1952 
[12] Touaibia, B. (2010) Problems of Erosion and Sediment Transport in Northern Algeria [Problématique de l'érosion et du transport solide en Algérie septentrionale]. Sécheresse, 21, 1-6.

[13] Brondeau, F. (2005) Water Access, Differentiation Factor of Landscapes and Rural Societies: e.g. Irrigated Perimeters of the Office du Niger and Their Dry Borders [L'accès à l'eau, facteur de différenciation des paysages et des sociétés rurales: exemple des périmètres irrigués de l’Office du Niger et de leurs marges sèches]. http://www.secheresse.info/spip.php?article1817

[14] MAHRH (2002) Action Plan for Integrated Management of Water Resources (IWRM) (2003-2015). Volume 1: Strategic Plan of IWRM actions, 3rd version [Plan d'Action de Gestion Intégrée des Ressources en Eau (PAGIRE) (2003-2015). Tome 1: Plan d'actions stratégique de la GIRE, $3^{\text {ème }}$ version]. DGIRH/DANIDA, Ouagadougou/Burkina Faso, 52 p.

[15] MEE/GIRE (2001) Inventory of Water Resources in Burkina Faso and Their Context Management. Final Version [Etat des lieux des ressources en eau du Burkina Faso et de leur cadre de gestion. Version finale]. MEE-SP, GIRE-May, Ouagadougou, 243 p.

[16] REEB (2002) Report on environment in Burkina Faso, Summury [Rapport sur l'état de l'environnement au Burkina Faso, Résumé]. Sp/CONAGESE, $1^{\text {rst }}$ Edition, March, Ouagadougou, 43 p.

[17] Berton, S. (1987) Flood Control in the Lowlands. Small and Micro-Dams in West Africa [La maîtrise des crues dans les bas-fonds. Petits et micro-barrages en Afrique de l’Ouest]. Schedule 3rd-party, French Cooperation/GRET/ACCT, Paris, 302-474.

[18] Couture, J.-L. (1999) Documentary Study on Water Management in Sub-Saharan and Caribbean Region [Etude documentaire sur la gestion de l'eau en Afrique sub-saharienne et région Caraïbes]. CTA-Wageningen, Pays-Bas, 41 p.

[19] Global Water Partnership [Partenariat Mondial pour l’Eau] (2000) Integrated Water Resources Management. GWP/ Technical Advisory Committee [La gestion intégrée des ressources en eau. GWP/Comité Technique Consultatif (TAC)], Background Papers No. 4, Stockholm/Sweden, 76 p.

[20] Yabi, I., Afouda, F. and Boko, M. (2011) Some Socio-Economic Aspects of Irrigation Schemes in Response to Climate Change Impacts in Mono-Couffo Departments (Benin, West Africa) [Quelques aspects socio-économiques des aménagements hydro-agricoles en réponse aux impacts des changements climatiques dans les départements du Mono-Couffo (Bénin, Afrique de l'Ouest)], LACEEDE/DGAT/UAC, Cotonou, 13 p.

[21] LIFAD (2006) Management Systems Study/Water Use and Definition of the Priority Actions of Local Water Resources Development in IWRM Approach, Benin. Volume 1-Current Situation of Water Resources Management in Benin [Etude des systèmes de gestion/utilisation de l'eau et définition des actions prioritaires de valorisation locale des ressources eau dans une approche GIRE au Bénin. Volume 1-Etat des lieux de la gestion des ressources en eau du Bénin]. MMEE/LIFAD/Benin, $121 \mathrm{p}$.

[22] MEE/DRH/HB (1998) RESO: Strategic and Prospective Diagnosis of Water Sector in the Southwest. Technical File, Project 7 [RESO: Diagnostic stratégique et prospectif du secteur de l'eau dans le Sud-ouest. Dossier technique, Projet 7]. ACP-BK.017, BF-UE, Ouagadougou, 52 p.

[23] Diallo, M., Wellens, J., Dakoure, D. and Compaore, N.F. (2006) The Experience of Water Management Project in the Kou Basin in Burkina Faso: Promoting Innovative Approaches to Research and Development in Water [L'expérience du projet Gestion de l'Eau (GEau) dans le bassin du Kou au Burkina Faso: promouvoir des approches innovantes de recherche-développement en matière d'eau]. Unpublished paper, 11 p.

[24] Carre, A., Peguin, M. and Poulin, B. (2012) Red List of IUCN Ecosystems. Application Exercise on Some Wetlands Ecosystems in Mainland France [Liste rouge des écosystèmes de l’UICN. Exercice d'application sur quelques écosystèmes de Zones Humides de France métropolitaine]. UICN/Tour du Valat, Paris/France, 82 p.

[25] Mertz, O., D’haen, S., et al. (2012) Climate Variability and Environmental Stress in the Sudan-Sahel Zone of West Africa. AMBIO, Royal Swedish Academy of Sciences, 41, 380-392. http://dx.doi.org/10.1007/s13280-011-0231-8

[26] Dano Municipality [Commune de Dano] (2007) Municipal Development Plan. Final Edition [Plan Communal de Développement. Version définitive]. October, Dano, 128 p.

[27] Pale, S. (2009) Farmers' Perceptions of Climate Variability, Their Impact on the Environment and Agricultural Activities in Dano Department (Southwestern Burkina Faso) [Perception paysanne des variabilités climatiques, leurs incidences sur l'environnement et les activités agricoles dans le département de Dano (Sud-ouest du Burkina Faso)]. Master Dissertation, Department of Geography, University of Ouagadougou, 96 p.

[28] Roose, E., Albergel, J., De Noni, G., Laouina, A. and Sabir, M. (2008) Water Management Effectiveness and Soil Fertility in Semi-Arid Environments [Efficacité de la gestion de l'eau et de la fertilité des sols en milieux semi-arides]. AUF/IRD/ENFI/EAC, Paris, 425 p.

[29] Salack, S., Sultan, B., Oettli, P., Muller, B., Gaye, A.T. and Hourdin, F. (2012) Rain Representation in Regional Climate Models and Application to Millet Yields Estimation in Senegal [Représentation de la pluie dans les modèles régionaux de climat et application à l’estimation des rendements du mil au Sénégal]. Sécheresse, 23, 14-23. 
[30] BUNASOLS (2000) Morpho-Pedological Study of Bougouriba and Ioba Provinces. Scale 1/1000.000—Technical Report No. 121 [Etude morphopédologique des provinces de la Bougouriba et du Ioba. Echelle 1/1000.000—Rapport technique $\left.\mathrm{N}^{\circ} 121\right], 69 \mathrm{p}+$ annexes.

[31] Dreyer Foundation and AGRITECH-Faso (2010). Integrated development program of the Municipality of Dano (PDIC/D) [Programme de développement intégré de la Commune de Dano (PDIC/D)]. Municipality of Dano/ AGRITECH-Faso/Dreyer Foundation, Dano, 117 p.

[32] Roose, E. (2007) Restoring the Productivity of Tropical Soils [Restauration de la productivité des sols tropicaux]. Acts of JSIRAUF, Hanoi, 6-7 november, 6 p.

[33] MAHRH (2008) Capitalization of Best Practices and Technologies in Irrigated Agriculture [Capitalisation des bonnes pratiques et technologies en agriculture irriguée]. SG/MAHRH—ARSA/PNUD, june, Ouagadougou, 168 p.

[34] MAHRH (2004) Legal Status of River Basin Organizations in Burkina Faso and Institution of the Financial Contri- bution in Terms of Water According to the Orientation Law Related to Water Management [Statut juridique des organismes de bassins hydrographiques du Burkina Faso et Institution de la contribution financière en matière d'eau selon la loi d'orientation relative à la gestion de l'eau]. SG/DGIRH, nov. Ouagadougou, $61 \mathrm{p}$.

[35] Some, J.-M. (2013) My Fight for Land [Mon combat pour la terre]. KARTHALA Editions, Paris, 256 p.

[36] Ballo, Y., Coulibaly, A., Alassane, D. and Yattara, K. (2006) Issues of Equality Lowland Resources Access. Evidence, Importance, Factors and Impacts on Lowlands Development [Problématique d'accès des genres aux ressources des bas-fonds. Témoignages, importance, facteurs et impacts sur l’aménagement des bas-fonds]. DIC-PT N²6, DDC/ Intercooperation Bern et DIC au Sahel, Ouagadougou, 22 p.

[37] Kuba, R. (2004) The Ritual Grammar Hierarchies: Migration and Land Chiefs in Segmental Society (Burkina Faso) [La grammaire rituelle des hiérarchies: migrations et chefs de terre dans une société segmentaire (Burkina Faso)]. Autrepart, No. 30, 63-76. http://dx.doi.org/10.3917/autr.030.0063

[38] Some, M. (1999) The Sacred and the Traditional Political System of Dagara in Burkina, on Colonization Toil [Le sacré et le système politique traditionnel des Dagara du Burkina à l'épreuve de la colonisation]. Revue CAMES: Sciences sociales et humaines-Serie B, 1, 74-89.

[39] CODDE (2006) The Release and Subsidies Impact on Rice Sector in Burkina Faso [L'impact de la libération et des subventions sur la filière riz au Burkina Faso]. Ouagadougou, 95 p.

[40] MEE/GIRE (2000) Sociological Issues Concerning Water Resources Management in Burkina Faso. Sociological Technical Report No. 2 [Problématiques sociologiques concernant la gestion des ressources en eau du Burkina Faso. Rapport technique sociologique $\mathrm{N}^{\circ} 2$ ]. MEE/IWRM Program, December, Ouagadougou, 163 p.

[41] Fromageot, A. (2007) Vegetable Colonization of Small Dams Shores: A New Geography [Colonisation maraîchère des rives des petits barrages: une nouvelle géographie]. 098HYSOC, L'eau en partage, IRD/Abidjan, 229-243.

[42] Petitguyot, T., Rieu, T., Chohin-Kuper, A. and Doukkali, R. (2005) Irrigated Agriculture Modernization and Water Resources Sustainability in the Scope of Tadla in Morocco [Modernisation de l'agriculture irriguée et durabilité des ressources en eau dans le périmètre de Tadla au Maroc]. Acts of Seminar "Irrigated Agriculture Modernization", Rabat, 13 pages.

[43] Saidi, A., Hammami, M., Daghari, H., Hatira, A., Ltifi, W. and Hachani, K. (2010) Water and Salts Balances in the Irrigated Perimeter of Kalâat Landalous (Tunisia) [Bilans d'eau et des sels dans le périmètre irrigué de Kalâat Landalous (Tunisie)]. Sécheresse, 21, 1-5.

[44] Traore, B., Ouedraogo, O., Miwende, S. and Sanou, M. (2008) Diagnostic Study of Moutori Developed Plain: Farmers' Capacity Development Plan [Etude diagnostic de la plaine aménagé de Moutori: Plan de développe- ment des capacités des producteurs]. Dreyer Foundation /Municipality of Dano, Dano, 75 p + Annexes.

[45] DGPER (2011) National Strategy for Rice Development [Stratégie nationale de développement de la riziculture]. Ouagadougou/Burkina Faso, 43 p.

[46] Romagny, B. and Cudennec, C. (2006) Water Management in Arid Areas: Physical and Social Considerations to Identify the Relevant Territories in South-East Tunisia [Gestion de l'eau territoires pertinents dans le en milieu aride: Considérations physiques et sociales pour l'identification des Sud-Est tunisien]. http://developpementdurable.revues.org/1805

[47] Zammouri, A. and Dababi, M.S. (2007) Wild Runoff Control in Arid Areas by Conventional Retaining Structures in the Troughs (Jessours) and Storage Tanks (Majels and Fasguyas) [La maîtrise du ruissellement sauvage en zones arides par des ouvrages de retenue traditionnels dans les Talwegs (jessours) et des Citernes de Stockage (Majels et Fasguyas)]. ADD, Tunisie, 7 p. 